\title{
Structure-activity relationships and the cytotoxic effects of novel diterpenoid alkaloid derivatives against A549 human lung carcinoma cells
}

\author{
Koji Wada $\cdot$ Masaharu Hazawa $\cdot$ Kenji Takahashi $\cdot$ \\ Takao Mori • Norio Kawahara • Ikuo Kashiwakura
}

Received: 28 April 2010/Accepted: 5 July 2010/Published online: 14 August 2010

(c) The Author(s) 2010. This article is published with open access at Springerlink.com

\begin{abstract}
The cytotoxicity of three alkaloids from the roots of Aconitum yesoense var. macroyesoense as well as 36 semi-synthetic $\mathrm{C}_{20}$-diterpenoid atisine-type alkaloid derivatives against A549 human lung carcinoma cells was examined. Ten acylated alkaloid derivatives, pseudokobusine 11-veratroate (9), 11-anisoate (12), 6,11-dianisoate (14), 11-p-nitrobenzoate (18), 11,15-di-p-nitrobenzoate (22), 11-cinnamate (25) and 11-m-trifluoromethylbenzoate (27), and kobusine 11-p-trifluoromethylbenzoate (35), 11-mtrifluoromethylbenzoate (36) and 11,15-di-p-nitrobenzoate (39), exhibited cytotoxic activity, and 11,15-dianisoylpseudokobusine (16) was found to be the most potent cytotoxic agent. Their $\mathrm{IC}_{50}$ values against $\mathrm{A} 549$ cells ranged from 1.72 to $5.44 \mu \mathrm{M}$. In the occurrence of cytotoxic effects of atisine-type alkaloids, replacement by an acyl group at both $\mathrm{C}-11$ and $\mathrm{C}-15$ resulted in the enhancement of activity of the parent alkaloids compared to that from having hydroxy groups at this position, and the presence of a hydroxy group at the C-6 position was required for the cytotoxic effects. These acylated alkaloid derivatives inhibit cell growth through G1 arrest.
\end{abstract}

K. Wada $(\bowtie)$

School of Pharmacy, Hokkaido Pharmaceutical University,

7-1 Katsuraoka-cho, Otaru, Hokkaido 047-0264, Japan

e-mail: kowada@hokuyakudai.ac.jp

M. Hazawa $\cdot$ K. Takahashi · I. Kashiwakura

Graduate School of Health Sciences, Hirosaki University,

66-1 Hon-cho, Hirosaki, Aomori 036-8564, Japan

T. Mori · N. Kawahara

Research Center, North Japan Chemical, Inc., Eniwa RBP 308,

1-1, 3-Meguminokita, Eniwa, Hokkaido 061-1374, Japan
Keywords Diterpenoid alkaloids · Pseudokobusine · Kobusine $\cdot$ Cytotoxic agents $\cdot$ A549 human lung carcinoma cells $\cdot$ Structure-activity relationship

\section{Introduction}

Diterpenoid alkaloids are classified according to their chemical structure as $\mathrm{C}_{19}$-norditerpenoid alkaloids, which consist of an aconitine or a lycoctonine skeleton, and $\mathrm{C}_{20^{-}}$ diterpenoid alkaloids, consisting of an atisine or a veatchine skeleton. A large number of diterpenoid alkaloids have been isolated from various species of Aconitum and Delphinium (Ranunculaceae) $[1,2]$. The pharmacological properties of $\mathrm{C}_{19}$-norditerpenoid alkaloids, including aconitine, mesaconitine, hypaconitine and jesaconitine, have been studied extensively and reviewed [1, 2]. Aconitine and mesaconitine are representative toxins that exhibit activity both centrally and peripherally, with predominant effects on the cardiovascular and respiratory systems, by preventing the normal closing of sodium channels [3, 4]. In contrast, there is little information regarding the pharmacological properties of $\mathrm{C}_{20}$-diterpenoid alkaloids and their chemically transformed products. Kobusine (1) and pseudokobusine (2), the major alkaloid constituents of Aconitum yesoense var. macroyesoense, and certain semisynthetic derivatives of diterpenoid alkaloids have been shown by using a Doppler-type laser blood flow meter to significantly increase cutaneous blood flow in the hind feet of anaesthetized mice [5-7].

The majority of drugs used in cancer chemotherapy can be divided into alkylating agents, anti-metabolites, antibiotics, plant alkaloids, topoisomerase inhibitors, monoclonal antibodies and other antitumor agents [8-16]. However, little information on the cytotoxic properties of Aconitum 
alkaloids has been reported, despite their intense toxicities. Two reports on the effects of $\mathrm{C}_{19}$-norditerpenoid alkaloids on cancer cells have appeared in recent years. 8-O-Azeloyl14-benzoylaconine, an aconitine-type $\mathrm{C}_{19}$-norditerpenoid alkaloid, exhibited anti-proliferative activity [17] and the cytotoxic effects of various $\mathrm{C}_{19}$-norditerpenoid alkaloids against tumor cell lines have been reported [18]. Our previous study demonstrated the effects of various naturally occurring and semi-synthetic diterpenoid alkaloids on the growth of the A172 human malignant glioma cell line [19]. The results of previous studies showed that seven acylated alkaloid derivatives, 12-acetylluciculine, pseudokobusine 11-veratroate (9), 11-anisoate (12), 11-p-nitrobenzoate (18), 11-cinnamate (25) and 11-m-trifluoromethylbenzoate (27), and 11-( $m$-trifluoromethylbenzoyl)kobusine (36), had significant cytotoxic effects on the growth of A172 cells. Esterification of the hydroxyl group at C-11 may, thus, contribute to the enhancement of activity of the parent alkaloids more than that of the $\mathrm{OH}$ group at $\mathrm{C}-11$. Cytotoxic properties and radiation-sensitizing effects of various types of novel derivatives prepared from Aconitum alkaloids have also been investigated [20]. 11-Anisoylpseudokobusine (12) and 11-m-trifluoromethylbenzoyl pseudokobusine (36) showed significant suppressive effects against the non-Hodgkin's lymphoma Raji cell line [21]. 11-m-Trifluoromethylbenzoylpseudokobusine (36) clearly inhibited the phosphorylation of extracellular signal-regulated kinase, induced enhanced phosphoinositide 3-kinase phosphorylation and led to the subsequent accumulation of G1 and/or sub-G1 phase in Raji cells. In addition, suppressive effects of 11-anisoylpseudokobusine (12) and 11- $m$-trifluoromethylbenzoylpseudokobusine (36) on the growth of human $\mathrm{CD} 34^{+}$hematopoietic stem/progenitor cells were observed.

In the present study, the effects of various semi-synthetic novel $\mathrm{C}_{20}$-diterpenoid alkaloids on the growth of the A549 human lung cancer cell line were examined. Twenty novel derivatives were prepared from natural compounds. In order to carry out structure-activity relationship studies of the anti-proliferative effect against A549 cells, three natural and 36 semi-synthetic diterpenoid alkaloids were tested.

\section{Materials and methods}

General experimental procedures

Melting points were determined on a Yanagimoto micro melting point apparatus and are uncorrected. ${ }^{1} \mathrm{H}-\mathrm{NMR}$ spectra in $\mathrm{CDCl}_{3}$ were recorded on JEOL GX-270 and AL-400 spectrometers using tetramethylsilane as an internal standard. Chemical shifts are given in ppm. Electron impact (EI) mass spectra were measured on Hitachi M-2000 and JEOL JMS-700 spectrometers. IR spectra were recorded with an IR spectrophotometer, Perkin-Elmer Spectrum 100. All products reported showed ${ }^{1} \mathrm{H}-\mathrm{NMR}$ spectra and mass spectra in agreement with the assigned structures. Reactions were carried out under an inert atmosphere of dry nitrogen or argon, unless otherwise described. Standard syringe techniques were used for transferring dry solvents. Reaction courses and product mixtures were monitored routinely by TLC on silica gel (precoated Merck $\mathrm{F}_{254}$ plates) and visualized with Dragendorff reagent. Chromatography was performed using silica gel and the indicated solvent system. All other chemicals used were of analytical grade.

\section{Alkaloids}

The diterpenoid alkaloids kobusine (1), pseudokobusine (2) and 15-veratroylpseudokobusine (10) were used after extraction from the roots of $A$. yesoense var. macroyesoense, followed by purification and identification by methods described previously [22, 23]. Thirty acyl derivatives, $N$-benzyl- $N$,6-seco-6-dehydropseudokobusine (3) [19], $N, 15$-dibenzyl- $N$,6-seco-6-dehydropseudokobusine (4) [19], 6-benzoylpseudokobusine (5) [23], 6,11-dibenzoylpseudokobusine (6) [23], 15-benzoyl-6,11-di-p-nitrobenzoylpseudokobusine (7) [19], 6-veratroylpseudokobusine (8) [7], 11-veratroylpseudokobusine (9) [7], 6-anisoylpseudokobusine (11) [7], 11-anisoylpseudokobusine (12) [7], 15-anisoylpseudokobusine (13) [7], 6,11-dianisoylpseudokobusine (14) [7], 6,15-dianisoylpseudokobusine (15) [7], 11,15dianisoylpseudokobusine (16) [7], 6-p-nitrobenzoylpseudokobusine (17) [23], 11-p-nitrobenzoylpseudokobusine (18) [7], 15-p-nitrobenzoylpseudokobusine (19) [24], 6,11-di- $p$-nitrobenzoylpseudokobusine (20) [24], 6,15-di- $p$ nitrobenzoylpseudokobusine (21) [24], 11,15-di-p-nitrobenzoylpseudokobusine (22) [7], 6,11,15-tri-p-nitrobenzoyl pseudokobusine (23) [24], 6-cinnamoylpseudokobusine (24) [6], 11-cinnamoylpseudokobusine (25) [6], 6-( $m$-trifluoromethylbenzoyl)pseudokobusine (26) [19], 11-( $m$-trifluoromethylbenzoyl)pseudokobusine (27) [19], 11-benzoyl kobusine (30) [6], 11-anisoylkobusine (31) [7], 11-veratroylkobusine (32) [7], dihydrokobusine (33) [7], 11-cinna moylkobusine (34) [6] and 11-( $m$-trifluoromethylbenzoyl)kobusine (36) [19], were prepared by methods described previously. Six semi-synthetic derivatives, 6-( $p$-trifluoromethylbenzoyl)pseudokobusine (28), 11-( $p$-trifluoromethylbenzoyl)pseudokobusine (29), 11-( $p$-trifluoromethylbenzoyl)kobusine (35), 11-p-nitrobenzoylkobusine (37), 15-p-nitrobenzoylkobusine (38) and 11,15-di-p-nitrobenzoylkobusine (39), were prepared from kobusine (1) and pseudokobusine (2). These semi-synthetic alkaloids were synthesized at controlled reaction times and temperatures. 
Synthesis of 6-(28) and 11-(p-trifluoromethylbenzoyl) pseudokobusine (29)

A solution of $2(0.111 \mathrm{~g}, 0.34 \mathrm{mmol})$ and $p$-trifluoromethylbenzoyl chloride $(0.1 \mathrm{ml}, 0.67 \mathrm{mmol})$ in pyridine $(2 \mathrm{ml})$ was stirred for $30 \mathrm{~min}$ at ambient temperature. After adding water, the reaction mixture was extracted with chloroform after the addition of aqueous $\mathrm{NH}_{4} \mathrm{OH}$. The organic layer was washed with aqueous saturated $\mathrm{NaHCO}_{3}$ and brine, and then dried over anhydrous $\mathrm{MgSO}_{4}$. The solvent was evaporated under reduced pressure and the resulting residue was purified by silica gel column chromatography eluting with $1 \%$ methanol- $-\mathrm{NH}_{4} \mathrm{OH}$-saturated $\mathrm{CHCl}_{3}$ to give $28(19 \mathrm{mg}, 11 \%), 29(34 \mathrm{mg}, 20 \%)$ and 2 (14 mg). 6-( $p$-Trifluoromethylbenzoyl)pseudokobusine (28): amorphous. ${ }^{1} \mathrm{H}-\mathrm{NMR}\left(\mathrm{CDCl}_{3}, 400 \mathrm{MHz}\right) \delta$ : $0.98(3 \mathrm{H}$, s, H-18), $3.96(1 \mathrm{H}, \mathrm{s}, \mathrm{H}-15), 4.08(1 \mathrm{H}, \mathrm{d}, J=4.8 \mathrm{~Hz}$, $\mathrm{H}-11), 5.14$ and 5.24 (each $1 \mathrm{H}, \mathrm{s}, \mathrm{H}-17), 7.71(2 \mathrm{H}, \mathrm{d}$, $J=8.0 \mathrm{~Hz}, \mathrm{H}-\mathrm{Ar}), 8.16(2 \mathrm{H}, \mathrm{d}, J=8.0 \mathrm{~Hz}, \mathrm{H}-\mathrm{Ar}) . \mathrm{IR}$ (ATR) $\mathrm{cm}^{-1}:$ 3316, 1726, 1562, 1322, 1259, 1163, 896. EIMS $m / z: 501\left(\mathrm{M}^{+}\right), 429,329,190,173$. HREIMS $m / z$ : 501.2130 (calcd. for $\mathrm{C}_{28} \mathrm{H}_{30} \mathrm{~F}_{3} \mathrm{NO}_{4}$ : 501.2127). 11-( $p$-Trifluoromethylbenzoyl)pseudokobusine (29): colorless crystals (acetone-hexane), mp $293^{\circ} \mathrm{C}$ (dec.). ${ }^{1} \mathrm{H}-\mathrm{NMR}\left(\mathrm{CDCl}_{3}\right.$, $400 \mathrm{MHz}) \delta: 1.18(3 \mathrm{H}, \mathrm{s}, \mathrm{H}-18), 4.00(1 \mathrm{H}, \mathrm{s}, \mathrm{H}-15), 5.06$ and $5.23($ each $1 \mathrm{H}, \mathrm{s}, \mathrm{H}-17), 5.32(1 \mathrm{H}, \mathrm{d}, J=4.8 \mathrm{~Hz}$, $\mathrm{H}-11), 7.64(1 \mathrm{H}, \mathrm{d}, J=8.3 \mathrm{~Hz}, \mathrm{H}-\mathrm{Ar}), 8.00(1 \mathrm{H}, \mathrm{d}$, $J=8.3 \mathrm{~Hz}, \mathrm{H}-\mathrm{Ar}$ ). IR (ATR) $\mathrm{cm}^{-1}: 3291,1717,1557$, 1323, 1267, 1166, 901. EIMS $m / z: 501\left(\mathrm{M}^{+}\right), 328,173$. HREIMS $\mathrm{m} / \mathrm{z}: 501.2125$ (calcd. for $\mathrm{C}_{28} \mathrm{H}_{30} \mathrm{~F}_{3} \mathrm{NO}_{4}$ : 501.2127).

Synthesis of 11-( $p$-trifluoromethylbenzoyl)kobusine (35)

A solution of $1(0.041 \mathrm{~g}, 0.13 \mathrm{mmol})$ and $p$-trifluoromethylbenzoyl chloride $(0.04 \mathrm{ml}, 0.26 \mathrm{mmol})$ in pyridine $(1 \mathrm{ml})$ was stirred for $1.5 \mathrm{~h}$ at $0^{\circ} \mathrm{C}$ (ice bath). After adding water, the reaction mixture was extracted with chloroform after the addition of aqueous $\mathrm{NH}_{4} \mathrm{OH}$. The organic layer was washed with aqueous saturated $\mathrm{NaHCO}_{3}$ and brine, and then dried over anhydrous $\mathrm{Na}_{2} \mathrm{SO}_{4}$. The solvent was evaporated under reduced pressure, and the resulting residue was purified by silica gel column chromatography eluting with $2 \%$ methanol- $\mathrm{NH}_{4} \mathrm{OH}$-saturated $\mathrm{CHCl}_{3}$ to give 35 (16 mg, 26\%). 11-(p-Trifluoromethylbenzoyl)kobusine (35): white crystals (acetone-hexane), mp 213-216 ${ }^{\circ} \mathrm{C} .{ }^{1} \mathrm{H}-\mathrm{NMR}\left(\mathrm{CDCl}_{3}, 400 \mathrm{MHz}\right) \delta: 0.98(3 \mathrm{H}, \mathrm{s}$, $\mathrm{H}-18), 4.03(1 \mathrm{H}, \mathrm{s}, \mathrm{H}-15), 5.08$ and $5.25($ each $1 \mathrm{H}, \mathrm{s}$, $\mathrm{H}-17), 5.41(1 \mathrm{H}, \mathrm{d}, J=4.8 \mathrm{~Hz}, \mathrm{H}-11), 7.69(2 \mathrm{H}, \mathrm{d}$, $J=8.3 \mathrm{~Hz}, \mathrm{H}-\mathrm{Ar}), 8.07(2 \mathrm{H}, \mathrm{d}, J=8.3 \mathrm{~Hz}, \mathrm{H}-\mathrm{Ar}) . \mathrm{IR}$ (ATR) $\mathrm{cm}^{-1}: 3361,1718,1555,1323,1275,1164,895$.
EIMS $\mathrm{m} / \mathrm{z}: 485\left(\mathrm{M}^{+}\right), 312,296,173$. HREIMS $\mathrm{m} / \mathrm{z}$ : 485.2157 (calcd. for $\mathrm{C}_{28} \mathrm{H}_{30} \mathrm{~F}_{3} \mathrm{NO}_{3}$ : 485.5376).

Synthesis of 11-(37), 15- (38) and 11,15-di-pnitrobenzoylkobusine (39)

A solution of $1(0.106 \mathrm{~g}, 0.34 \mathrm{mmol})$ and p-nitrobenzoyl chloride $(0.252 \mathrm{mg}, 1.36 \mathrm{mmol})$ in pyridine $(2 \mathrm{ml})$ was stirred for $2 \mathrm{~h}$ at $0^{\circ} \mathrm{C}$ (ice bath). After adding water, the reaction mixture was extracted with chloroform after the addition of aqueous $\mathrm{NH}_{4} \mathrm{OH}$. The organic layer was washed with aqueous saturated $\mathrm{NaHCO}_{3}$ and brine, and then dried over anhydrous $\mathrm{MgSO}_{4}$. The solvent was evaporated under reduced pressure, and the resulting residue was purified by silica gel column chromatography eluting with $0.5 \%$ methanol- $\mathrm{NH}_{4} \mathrm{OH}-$ saturated $\mathrm{CHCl}_{3}$ to give 37 (55 mg, 35\%), $\mathbf{3 8}$ (14 mg, 9\%), $\mathbf{3 9}$ (52 mg, 25\%) and 1 (4 mg). 11-p-Nitrobenzoylkobusine (37): amorphous. ${ }^{1} \mathrm{H}-\mathrm{NMR}\left(\mathrm{CDCl}_{3}, 270 \mathrm{MHz}\right) \delta: 0.99(3 \mathrm{H}, \mathrm{s}, \mathrm{H}-18)$, $4.05(1 \mathrm{H}, \mathrm{d}, J=5.6 \mathrm{~Hz}, \mathrm{H}-15), 5.08$ and $5.25($ each $1 \mathrm{H}, \mathrm{s}$, $\mathrm{H}-17), 5.42(1 \mathrm{H}, \mathrm{d}, J=4.9 \mathrm{~Hz}, \mathrm{H}-11), 8.13(2 \mathrm{H}, \mathrm{d}$, $J=8.5 \mathrm{~Hz}, \mathrm{H}-\mathrm{Ar}), 8.28(2 \mathrm{H}, \mathrm{d}, J=8.5 \mathrm{~Hz}, \mathrm{H}-\mathrm{Ar}) . \mathrm{IR}$ (ATR) $\mathrm{cm}^{-1}: 3377,1717,1605,1525,1279,1103,900$. EIMS $\mathrm{m} / \mathrm{z}: 462\left(\mathrm{M}^{+}\right), 433,312,295$. HREIMS $\mathrm{m} / \mathrm{z}$ : 462.2179 (calcd. for $\mathrm{C}_{27} \mathrm{H}_{30} \mathrm{~N}_{2} \mathrm{O}_{5}: 462.2153$ ). 15-p-Nitrobenzoylkobusine (38): colorless crystals (acetone-hexane), mp 214-216 ${ }^{\circ} \mathrm{C} .{ }^{1} \mathrm{H}-\mathrm{NMR}\left(\mathrm{CDCl}_{3}, 270 \mathrm{MHz}\right) \delta: 0.96(3 \mathrm{H}$, $\mathrm{s}, \mathrm{H}-18), 4.14(1 \mathrm{H}, \mathrm{d}, J=4.6 \mathrm{~Hz}, \mathrm{H}-11), 5.25$ and 5.39 (each 1H, s, H-17), $5.73(1 \mathrm{H}, \mathrm{s}, \mathrm{H}-15), 8.21(2 \mathrm{H}, \mathrm{d}$, $J=8.9 \mathrm{~Hz}, \mathrm{H}-\mathrm{Ar}), 8.30(2 \mathrm{H}, \mathrm{d}, J=8.9 \mathrm{~Hz}, \mathrm{H}-\mathrm{Ar}) . \mathrm{IR}$ (ATR) $\mathrm{cm}^{-1}: 3055,1710,1606,1524,1269,1104,901$. EIMS $\mathrm{m} / \mathrm{z}: 462\left(\mathrm{M}^{+}\right), 432,312,296$. HREIMS $\mathrm{m} / \mathrm{z}$ : 462.2131 (calcd. for $\mathrm{C}_{27} \mathrm{H}_{30} \mathrm{~N}_{2} \mathrm{O}_{5}$ : 462.2153). 11,15-pNitrobenzoylkobusine (39): colorless crystals (acetonehexane), mp $232-233^{\circ} \mathrm{C} .{ }^{1} \mathrm{H}-\mathrm{NMR}\left(\mathrm{CDCl}_{3}, 270 \mathrm{MHz}\right) \delta$ : 0.97 (3H, s, H-18), 5.19 and 5.41 (each $1 \mathrm{H}, \mathrm{s}, \mathrm{H}-17), 5.51$ $(1 \mathrm{H}, \mathrm{d}, J=4.6 \mathrm{~Hz}, \mathrm{H}-11), 5.81(1 \mathrm{H}, \mathrm{s}, \mathrm{H}-15), 8.02(2 \mathrm{H}, \mathrm{d}$, $J=8.9 \mathrm{~Hz}, \mathrm{H}-\mathrm{Ar}), 8.05(4 \mathrm{H}, \mathrm{d}, J=8.9 \mathrm{~Hz}, \mathrm{H}-\mathrm{Ar}), 8.07$ $\left(2 \mathrm{H}, \mathrm{d}, J=8.3 \mathrm{~Hz}, \mathrm{H}-\mathrm{Ar}\right.$ ). IR (ATR) $\mathrm{cm}^{-1}: 3073,1711$, 1606, 1524, 1260, 1102, 902. EIMS $\mathrm{m} / \mathrm{z}: 611\left(\mathrm{M}^{+}\right), 581$, 461, 432. HREIMS m/z: 611.2265 (calcd. for $\mathrm{C}_{34} \mathrm{H}_{33} \mathrm{~N}_{3} \mathrm{O}_{8}$ : 611.2265).

Inhibition of growth of the human lung cancer cell line A549

All test alkaloids were dissolved in dimethyl sulfoxide (DMSO) at 1 or $5 \mathrm{mg} / \mathrm{ml}$ immediately before use and diluted in the medium before addition to the cells. Cells were cultured in a DMEM medium supplemented with $10 \%$ heat-inactivated fetal bovine serum and antibiotics [penicillin $(100 \mathrm{UI} / \mathrm{ml})$ and streptomycin $(100 \mathrm{UI} / \mathrm{ml})]$. 
To determine the effects of alkaloids on cell growth, exponentially growing A549 cells $\left(4 \times 10^{3}\right.$ cells/well $)$ were seeded in 24-well plates (Falcon, Becton-Dickinson Biosciences, Franklin Lakes, NJ, USA) with $500 \mathrm{ml}$ of medium, and each alkaloid (final concentration: 1 or $5 \mu \mathrm{g} / \mathrm{ml}$ ) was added to each plate $24 \mathrm{~h}$ later. The total cell numbers were determined after 3 days using a particle counter (model $\mathrm{Z}^{\mathrm{TM}}$ series, Coulter Electronics, Hialeah, FL, USA). The results are expressed as inhibition values in comparison to untreated controls and as $\mathrm{IC}_{50}$ values (concentration causing 50\% inhibition relative to untreated controls). All experiments were repeated at least three times. Excluding the possible anti-proliferative effects of DMSO, the maximum concentration of DMSO $(0.5 \%)$ was used in control culture and did not affect the growth of A549 cells. Pemetrexed (Eli Lily and Company, Indianapolis, IN, USA) was used as the reference control.

\section{Cell cycle analysis by flow cytometry}

A549 cells were treated with each compound at doses of its $\mathrm{IC}_{50}$ and double $\mathrm{IC}_{50}$ values and incubated for $24 \mathrm{~h}$. The harvested cells were treated with PBS containing $0.1 \%$ Triton X-100 (Wako) and were stained with propidium iodide $(50 \mu \mathrm{g} / \mathrm{ml}$, Sigma). Analysis of cell cycle distribution was performed using a flow cytometer (BeckmanCoulter, Cell Lab Quanta $^{\mathrm{TM}}$ SC MPL, Fullerton, CA, USA).

\section{Statistical analysis}

The data are expressed as the mean \pm SD of 3 cultures of a group, and the significance of differences between the control and experimental groups were determined using either Student's $t$ test or Mann-Whitney's $U$-test, depending on the data distribution. Statistical analysis was performed using the Excel 2003 software package (Microsoft, Redmond, WA, USA) with the add-in software Statcel 2 (OMS, Saitama, Japan).

\section{Results and discussion}

Aconitum diterpenoid alkaloids and their novel derivatives were examined for the suppressive effects on the growth of the A549 human lung cancer cell line [20]. $\mathrm{C}_{19}$-norditerpenoid aconitine-type alkaloids (five alkaloids) and lycoctonine-type alkaloids (seven alkaloids) were found to be inactive. Among the seven $\mathrm{C}_{20}$-diterpenoid veatchinetype alkaloids tested, 12-acetylluciculine and 12-benzoylluciculine showed slight inhibitory activities against growth.
Alkaloids $\mathbf{1}$ and $\mathbf{2}$ contain two and three hydroxy groups, respectively, in the common basic structure of the atisine skeleton, being devoid of any other substituents. In the molecules of $\mathbf{1}$ and $\mathbf{2}$ (Fig. 1), semi-synthetic derivatives were tested for suppressive effects at $1 \mu \mathrm{g} / \mathrm{ml}$ additions and $\mathrm{IC}_{50}$ values against the growth of A549 cells were examined (Table 1). $\quad N$-Benzyl- $N, 6$-seco-6-dehydropseudokobusine (3) and $N, 15$-dibenzyl- $N$,6-seco-6-dehydropseudokobusine (4) were inactive. Among the benzoyl derivatives (5-7) of 2, 6-benzoylpseudokobusine (5) and 15-benzoyl-6,11-di-pnitrobenzoylpseudokobusine (7) were inactive. 6,11Dibenzoylpseudokobusine (6) had a weak cytotoxic effect, which was altered by an aryl substituent at $\mathrm{C}-11$ or by a hydroxy group at C-15. Among the veratroyl derivatives (810) of 2, 6-veratroylpseudokobusine (8) was inactive. 15-Veratroylpseudokobusine (10) displayed little cytotoxic effect. In contrast, 11-veratroylpseudokobusine (9) had a significant cytotoxic effect. Therefore, the suppressive effects were elicited by the presence of an acyl substituent at C-11. Among the anisoyl (11-16) and p-nitrobenzoyl (17-23) derivatives of 2, 6-anisoylpseudokobusine (11), 6,15dianisoylpseudokobusine (15), 6,15-di-p-nitrobenzoylpseudokobusine (21) and 6,11,15-tri-p-nitrobenzoylpseudokobusine (23) were inactive. 6-p-Nitrobenzoylpseudokobusine (17) and 15-p-nitrobenzoylpseudokobusine (19) displayed little cytotoxic effect, and 15-anisoylpseudokobusine (13) and 6,11-di-p-nitrobenzoylpseudokobusine (20) showed only weak cytotoxic effects. 11-Anisoylpseudokobusine (12), 6,11-dianisoylpseudokobusine (14), 11,15-dianisoylpseudokobusine (16), 11-p-nitrobenzoylpseudokobusine (18) and 11,15-di-p-nitrobenzoylpseudokobusine (22) had significant cytotoxic effects. Accordingly, the cytotoxic effects of 6-substrates $(\mathbf{1 1}, \mathbf{1 7})$ were weaker than those of 6,11-disubstrates $(\mathbf{1 4}, \mathbf{2 0})$, and 11-substrates $(\mathbf{1 2}, \mathbf{1 8})$ had more potent cytotoxic effects than those of 6,11-disubstrates $(\mathbf{1 4}, \mathbf{2 0})$. In fact, 11 -acyl derivatives $(\mathbf{2 5}, \mathbf{2 7})$ exhibited more potent cytotoxic effects than those of 6-substrates $(\mathbf{2 4}, \mathbf{2 6})$, but $p$-trifluoromethylbenzoyl derivatives $(\mathbf{2 8}, \mathbf{2 9})$ were inactive. In addition 11,15-dianisoylpseudokobusine (16) and 11,15-di-p-nitrobenzoylpseudokobusine (22) were found to be about 1.3 -fold and 2 -fold more potent than 11-anisoylpseudokobusine (12) and 11-p-nitrobenzoylpseudokobusine (18), respectively. Substitution of the hydroxy group at $\mathrm{C}-11$ of pseudokobusine had variable effects. Benzoate (6) and $p$-trifluoromethylbenzoate (29) were in active. Veratroate $\left(\mathbf{9}, \mathrm{IC}_{50}=4.07 \mu \mathrm{M}\right), p$-nitrobenzoate $\left(\mathbf{1 8}, \mathrm{IC}_{50}=5.08 \mu \mathrm{M}\right)$, cinnamate $\left(\mathbf{2 5}, \mathrm{IC}_{50}=4.24 \mu \mathrm{M}\right)$ and $m$-trifluoromethylbenzoate $\left(27, \mathrm{IC}_{50}=4.67 \mu \mathrm{M}\right)$ showed significant cytotoxic effects. $p$-Trifluoromethylbenzoate (29) had little effect at $5 \mu \mathrm{g} / \mathrm{ml}$, whereas the effect of $m$-trifluoromethylbenzoate (27) was more potent than that of 29. As to the effects of the substitution position by these benzoyl groups, $m$-position gave good result. Anisoate 
$\left(12, \mathrm{IC}_{50}=2.20 \mu \mathrm{M}\right)$ was found to be about 2-fold more potent than these substrates. Consequently, in the occurrence of cytotoxic effects of atisine-type alkaloids, replacement by an acyl group at $\mathrm{C}-11$ resulted in the enhancement of activity of the parent alkaloids more than when a hydroxy group was present at this position, and the presence of a hydroxy group at the C-6 position was required for the cytotoxic effects. Furthermore, replacement by an acyl group at both $\mathrm{C}-11$ and C-15 [e.g., 11,15-dianisoylpseudokobusine (16) and 11,15-di-p-nitrobenzoylpseudokobusine (22)] was required for the enhancement of the cytotoxic effect of 11-substrates $(\mathbf{1 2}, \mathbf{1 8})$.

Similarly, the suppressive effects of kobusine derivatives (30-39) at $1 \mu \mathrm{g} / \mathrm{ml}$ additions and $\mathrm{IC}_{50}$ values against the growth of A549 cells were examined (Table 1). 11-Benzoylkobusine (30), 11-veratroylkobusine (32) and dihydrokobusine (33) were inactive. 11-Anisoylkobusine (31) and 11-cinnamoylkobusine (34) displayed little cytotoxic effects. 11-( $p$-Trifluoromethylbenzoyl)kobusine (35) and 11-( $m$-trifluoromethylbenzoyl)kobusine (36) had significant cytotoxic effects. Among the $p$-nitrobenzoyl derivatives (37-39) of 1, 11-p-nitrobenzoylkobusine (37) and 15-p-nitrobenzoylkobusine (38) had little cytotoxic effects, and the effect of $\mathbf{3 7}$ was slightly more potent than that of 38. However, 11,15-di-p-nitrobenzoylkobusine (39)
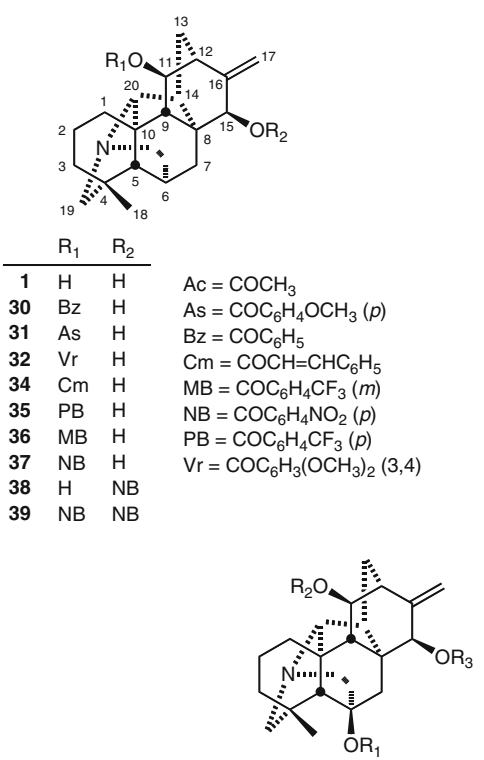

\begin{tabular}{rlll} 
& $\mathrm{R}_{1}$ & $\mathrm{R}_{2}$ & $\mathrm{R}_{3}$ \\
\hline $\mathbf{2}$ & $\mathrm{H}$ & $\mathrm{H}$ & $\mathrm{H}$ \\
$\mathbf{5}$ & $\mathrm{Bz}$ & $\mathrm{H}$ & $\mathrm{H}$ \\
$\mathbf{6}$ & $\mathrm{Bz}$ & $\mathrm{Bz}$ & $\mathrm{H}$ \\
$\mathbf{7}$ & $\mathrm{NB}$ & $\mathrm{NB}$ & $\mathrm{Bz}$ \\
$\mathbf{8}$ & $\mathrm{Vr}$ & $\mathrm{H}$ & $\mathrm{H}$ \\
$\mathbf{9}$ & $\mathrm{H}$ & $\mathrm{Vr}$ & $\mathrm{H}$ \\
$\mathbf{1 0}$ & $\mathrm{H}$ & $\mathrm{H}$ & $\mathrm{Vr}$ \\
$\mathbf{1 1}$ & $\mathrm{As}$ & $\mathrm{H}$ & $\mathrm{H}$ \\
$\mathbf{1 2}$ & $\mathrm{H}$ & $\mathrm{As}$ & $\mathrm{H}$
\end{tabular}

\begin{tabular}{llll} 
& $\mathrm{R}_{1}$ & $\mathrm{R}_{2}$ & $\mathrm{R}_{3}$ \\
\hline $\mathbf{1 3}$ & $\mathrm{H}$ & $\mathrm{H}$ & $\mathrm{As}$ \\
$\mathbf{1 4}$ & $\mathrm{As}$ & $\mathrm{As}$ & $\mathrm{H}$ \\
$\mathbf{1 5}$ & $\mathrm{As}$ & $\mathrm{H}$ & $\mathrm{As}$ \\
$\mathbf{1 6}$ & $\mathrm{H}$ & $\mathrm{As}$ & $\mathrm{As}$ \\
17 & $\mathrm{NB}$ & $\mathrm{H}$ & $\mathrm{H}$ \\
$\mathbf{1 8}$ & $\mathrm{H}$ & $\mathrm{NB}$ & $\mathrm{H}$ \\
19 & $\mathrm{H}$ & $\mathrm{H}$ & $\mathrm{NB}$ \\
$\mathbf{2 0}$ & $\mathrm{NB}$ & $\mathrm{NB}$ & $\mathrm{H}$ \\
$\mathbf{2 1}$ & $\mathrm{NB}$ & $\mathrm{H}$ & $\mathrm{NB}$
\end{tabular}

Fig. 1 Structure of $\mathrm{C}_{20}$-diterpenoid alkaloids and their derivatives
Table 1 Cytotoxic effects of atisine-type $\mathrm{C}_{20}$-diterpenoid alkaloids against A549 cell lines

\begin{tabular}{|c|c|c|c|}
\hline Compound & $1 \mu \mathrm{g} / \mathrm{ml}^{\mathrm{a}}$ & $5 \mu \mathrm{g} / \mathrm{ml}^{\mathrm{a}}$ & $\mathrm{IC}_{50}(\mu \mathrm{M})$ \\
\hline Control & 1.00 & 1.00 & - \\
\hline 1 & $1.07 \pm 0.16$ & $1.00 \pm 0.05$ & ND \\
\hline 2 & $1.12 \pm 0.16$ & $0.93 \pm 0.04$ & ND \\
\hline 3 & $1.01 \pm 0.03$ & ND & ND \\
\hline 4 & $0.98 \pm 0.02$ & ND & ND \\
\hline 5 & $1.02 \pm 0.01$ & ND & ND \\
\hline 6 & $0.88 \pm 0.06^{*}$ & ND & ND \\
\hline 7 & $0.96 \pm 0.06$ & ND & ND \\
\hline 8 & $0.98 \pm 0.06$ & $0.86 \pm 0.03$ & ND \\
\hline 9 & $0.65 \pm 0.06^{*}$ & ND & $4.07 \pm 0.00$ \\
\hline 10 & $0.94 \pm 0.01$ & ND & ND \\
\hline 11 & $1.02 \pm 0.01$ & $1.05 \pm 0.04$ & ND \\
\hline 12 & $0.65 \pm 0.08^{*}$ & ND & $2.20 \pm 0.11$ \\
\hline 13 & $0.89 \pm 0.03$ & $0.56 \pm 0.04 *$ & ND \\
\hline 14 & $0.66 \pm 0.04 *$ & $0.15 \pm 0.04 *$ & $3.68 \pm 0.30$ \\
\hline 15 & $1.04 \pm 0.14$ & $0.25 \pm 0.06^{*}$ & ND \\
\hline 16 & $0.54 \pm 0.14 *$ & $0.03 \pm 0.01 *$ & $1.72 \pm 0.03$ \\
\hline 17 & $0.93 \pm 0.04$ & $0.83 \pm 0.03$ & ND \\
\hline 18 & $0.75 \pm 0.08 *$ & ND & $5.08 \pm 0.15$ \\
\hline 19 & $0.93 \pm 0.05$ & $0.47 \pm 0.04 *$ & ND \\
\hline 20 & $0.86 \pm 0.11$ & $0.11 \pm 0.08^{*}$ & ND \\
\hline 21 & $0.98 \pm 0.11$ & $0.42 \pm 0.10^{*}$ & ND \\
\hline 22 & $0.74 \pm 0.14 *$ & $0.03 \pm 0.01 *$ & $2.66 \pm 0.21$ \\
\hline 23 & $1.05 \pm 0.06$ & $0.91 \pm 0.05$ & ND \\
\hline 24 & $0.95 \pm 0.04$ & $0.90 \pm 0.02$ & ND \\
\hline 25 & $0.59 \pm 0.10^{*}$ & ND & $4.24 \pm 0.00$ \\
\hline 26 & $1.05 \pm 0.06$ & ND & ND \\
\hline 27 & $0.69 \pm 0.09 *$ & ND & $4.67 \pm 0.08$ \\
\hline 28 & $1.03 \pm 0.05$ & $1.17 \pm 0.31$ & ND \\
\hline 29 & $1.09 \pm 0.19$ & $0.72 \pm 0.07 *$ & ND \\
\hline 30 & $1.06 \pm 0.19$ & $0.64 \pm 0.11^{*}$ & ND \\
\hline 31 & $0.98 \pm 0.14$ & $0.35 \pm 0.04^{*}$ & $11.42 \pm 0.71$ \\
\hline 32 & $1.04 \pm 0.25$ & $0.50 \pm 0.06^{*}$ & ND \\
\hline 33 & $1.09 \pm 0.06$ & $1.04 \pm 0.05$ & ND \\
\hline 34 & $0.93 \pm 0.19$ & $0.44 \pm 0.11^{*}$ & ND \\
\hline 35 & $0.72 \pm 0.11 *$ & $0.21 \pm 0.04^{*}$ & $5.44 \pm 0.41$ \\
\hline 36 & $0.64 \pm 0.06^{*}$ & ND & $3.75 \pm 0.14$ \\
\hline 37 & $0.91 \pm 0.19$ & $0.37 \pm 0.10^{*}$ & ND \\
\hline 38 & $0.92 \pm 0.23$ & $0.89 \pm 0.04^{*}$ & ND \\
\hline 39 & $0.75 \pm 0.22$ & $0.27 \pm 0.24 *$ & $3.02 \pm 0.47$ \\
\hline Pemetrexed & $0.14 \pm 0.05^{*}$ & $0.13 \pm 0.04 *$ & $0.48 \pm 0.07$ \\
\hline
\end{tabular}

had a significant cytotoxic effect and showed an $\mathrm{IC}_{50}$ value against A549 cells of $3.02 \pm 0.47 \mu \mathrm{M}$. The cytotoxic effects of kobusine derivatives were weak compared with 
the cytotoxic effects of pseudokobusine derivatives, except trifluoromethylbenzoate $(\mathbf{3 5}, \mathbf{3 6})$. Hence, the presence of a hydroxy group at the C-6 position enhanced the suppressive effects against the growth of A549 cells.

In a test at $5 \mu \mathrm{g} / \mathrm{ml}$ additions against the growth of A549 cells, 26 alkaloids $(\mathbf{1}, \mathbf{2}, \mathbf{8}, \mathbf{1 1}, \mathbf{1 3}-\mathbf{1 7}, \mathbf{1 9 - 2 4}, \mathbf{2 8}-35,37-$ 39) were examined. Pseudokobusine (2) and alkaloids 8, 17, 23, 24 and 38 displayed weak cytotoxic effects. Alkaloids 13, 19, 21, 29, 30, 32 and 34 had significant cytotoxic effects and were found to be about 1.4- to 2.4-fold more potent than $1 \mu \mathrm{g} / \mathrm{ml}$ addition. In contrast, alkaloids $\mathbf{1 4}, \mathbf{1 5}$, 20, 31, 35, 37 and 39 had significantly more potent cytotoxic effects and were found to be about 3- to 8-fold more potent than $1 \mu \mathrm{g} / \mathrm{ml}$ addition. Alkaloids 16 and 22 showed the strongest cytotoxic activities against A549 cells.

The cell cycle distribution of A549 cells at 24 and $48 \mathrm{~h}$ after treatment was analyzed by a fluorescence cell analyzer. Compounds 14, 16 and 35 showed remarkable enhancement at the $\mathrm{G} 1$ phase for up to double $\mathrm{IC}_{50}$ dose at 24 h (Fig. 2), and these compounds increased the G1 phase population of A549 cells in a time-dependent manner (Fig. 3). These results suggest that cytotoxic derivatives can disturb G1 to $\mathrm{S}$ phase entrance [25-27]. It is well established that cell cycle progression is highly dependent on cyclins, Cdks (cyclin-dependent kinases) and $\mathrm{Cdk}$ inhibitors [28]. Raf-MEK-Erk signaling and/or PTENPI3K-AKT signaling contributes to G1 to $S$ transition via subsequent cyclin production and the inhibition of MEK and PI3K activity induced complete G1 phase arrest [29].
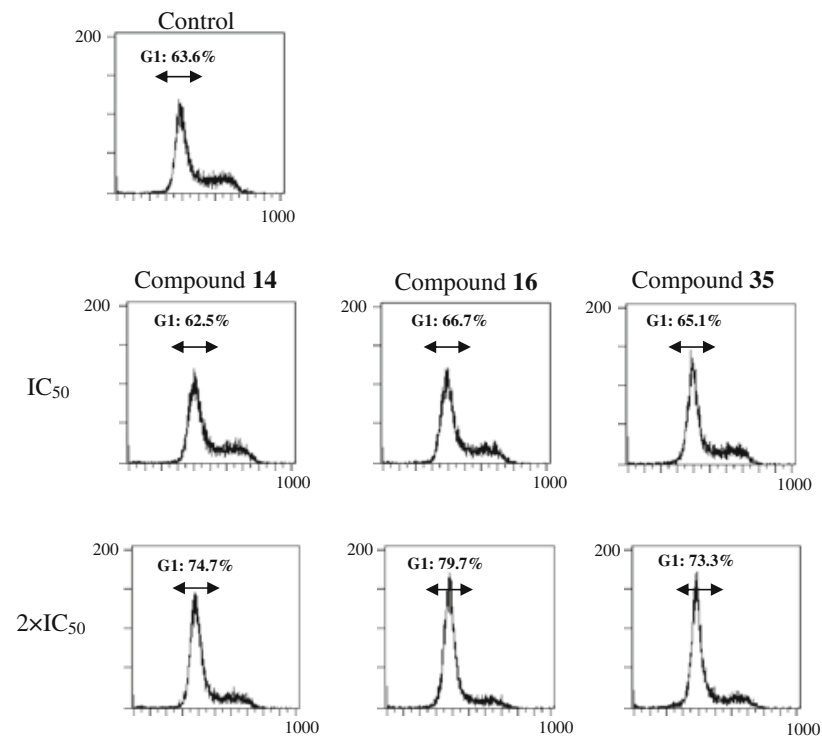

Fig. 2 The effects of compounds 14, 16 and 35 on the cell cycle distribution of A549 cells. A549 cells treated with vehicle (DMSO) alone and each compound at doses of its $\mathrm{IC}_{50}$ and double $\mathrm{IC}_{50}$ values for $24 \mathrm{~h}$ were fixed, and the cell cycle distribution was then analyzed by flow cytometry. Representative cytograms are shown

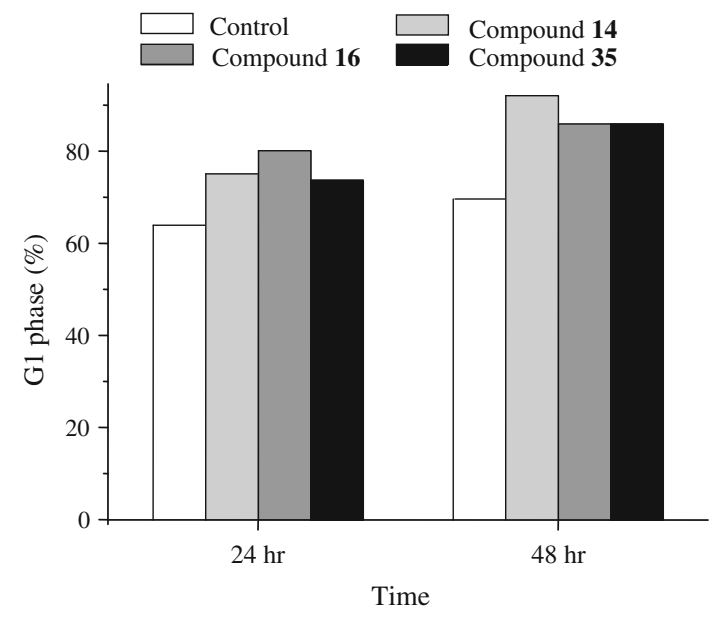

Fig. 3 The effects of compounds 14, 16 and 35 on the G1 phase population of A549 cells. A549 cells following treatment with vehicle alone and each compound at doses of double $\mathrm{IC}_{50}$ values for 24 and $48 \mathrm{~h}$

Moreover, in a previous study, a C-11 acyl derivative showed an inhibitory effect on the growth of A549 cells without enhancement of apoptosis or DNA damage [20]. Thus, it appears that these diterpenoid alkaloid derivatives do not induce genotoxic stress and inhibit cell growth through G1 arrest.

The results of this study suggest that C-6 and C-15 hydroxyl groups in pseudokobusine are necessary for a cytotoxic effect. Esterification of the hydroxyl group at C-11 may, thus, contribute to the enhancement of activity of the parent alkaloids more than that of the $\mathrm{OH}$ group at C-11. Furthermore, replacement by an acyl group at C-15 in 11-substrates, such as 11,15-dianisoylpseudokobusine (16), 11,15-di-p-nitrobenzoylpseudokobusine (22) and 11,15-di-p-nitrobenzoylkobusine (39), was involved in the activation of the cytotoxic effect. These three compounds incorporated all of the favorable modifications identified to date. They possess a novel structure and show remarkable $\mathrm{IC}_{50}$ value in the sub-micromolar range. Substitution of the hydroxyl group had variable effects. Benzoyl and benzyl substitutions were inactive. Cinnamoyl, $p$-nitrobenzoyl, $m$-trifluoromethylbenzoyl and veratroyl substitutions were effective. Anisoate was found to be about 2-fold more potent than these substrates. Current studies are focused on the use of semi-synthetic analogues of diterpenoid alkaloids to further probe the mechanisms of the cytotoxic effect on the growth of the A549 human lung cancer cell line. The present results suggested that novel alkaloid derivatives affect the metabolism of tumor cells as a part of the anti-proliferative activities. The suppressive effects of these alkaloids on the growth of human $\mathrm{CD}_{3} 4^{+}$hematopoietic stem/progenitor cells will be examined in the future. 
Open Access This article is distributed under the terms of the Creative Commons Attribution Noncommercial License which permits any noncommercial use, distribution, and reproduction in any medium, provided the original author(s) and source are credited.

\section{References}

1. Amiya T, Bando H (1988) Aconitum alkaloids. In: Brossi A (ed) The alkaloids, vol 34. Academic Press, San Diego, pp 95-179

2. Joshi BS, Pelletier SW (1999) Recent developments in the chemistry of norditerpenoid and diterpenoid alkaloids. In: Pelletier SW (ed) Alkaloids: chemical and biological perspectives, vol 13. Pergamon, Amsterdam, pp 289-370

3. Benn MH, Jacyno JM (1983) The toxicology and pharmacology of diterpenoid alkaloids. In: Pelletier SW (ed) Alkaloids: chemical and biological perspectives, vol 1. Wiley-Interscience, New York, pp 153-210

4. Fu M, Wu M, Qiao Y, Wang Z (2006) Toxicological mechanisms of Aconitum alkaloids. Pharmazie 61:735-741

5. Wada K, Ishizuki S, Mori T, Bando H, Murayama M, Kawahara $\mathrm{N}$ (1997) Effects of alkaloids from Aconitum yesoense var. macroyesoense on cutaneous blood flow in mice. Biol Pharm Bull 20:978-982

6. Wada K, Ishizuki S, Mori T, Fujihira E, Kawahara N (1998) Effects of Aconitum alkaloid kobusine and pseudokobusine derivatives on cutaneous blood flow in mice. Biol Pharm Bull 21:140-146

7. Wada K, Ishizuki S, Mori T, Fujihira E, Kawahara N (2000) Effects of Aconitum alkaloid kobusine and pseudokobusine derivatives on cutaneous blood flow in Mice; II. Biol Pharm Bull 23:607-615

8. Meng LH, Zhang JS, Ding J (2001) Salvicine, a novel DNA topoisomerase II inhibitor, exerting its effects by trapping enzymeDNA cleavage complexes. Biochem Pharmacol 62:733-741

9. Qing C, Jiang C, Zhang JS, Ding J (2001) Induction of apoptosis in human leukemia K-562 and gastric carcinoma SGC-7901 cells by salvicine, a novel anticancer compound. Anticancer Drugs $12: 51-56$

10. Didelot C, Mirjolet JF, Barberi-Heyob M, Ramacci C, Merlin JL (2002) Radiation could induce p53-independent and cell cycleunrelated apoptosis in 5-fluorouracil radiosensitized head and neck carcinoma cells. Can J Physiol Pharmacol 80:638-643

11. Baumann M, Krause M (2004) Targeting the epidermal growth factor receptor in radiotherapy: radiobiological mechanisms, preclinical and clinical results. Radiother Oncol 72:257-266

12. Haveman J, Castro-Kreder N, Rodermond HM, van Bree C, Franken NA, Stalpers LJ, Zdzienicka MZ, Peters GJ (2004) Cellular response of X-ray sensitive hamster mutant cell lines to gemcitabine, cisplatin and 5-fluorouracil. Oncol Rep 12:187-192

13. Sonnemann J, Gekeler V, Ahlbrecht K, Brischwein K, Liu C, Bader P, Müller C, Niethammer D, Beck JF (2004) Down-regulation of protein kinase $\mathrm{C} \eta$ by antisense oligonucleotides sensitises A549 lung cancer cells to vincristine and paclitaxel. Cancer Lett 209:177-185

14. Zhang M, Boyer M, Rivory L, Hong A, Clarke S, Stevens G, Fife $\mathrm{K}$ (2004) Radiosensitization of vinorelbine and gemcitabine in NCI-H460 non-small-cell lung cancer cells. Int J Radiat Oncol Biol Phys 58:353-360

15. Kvols LK (2005) Radiation sensitizers: a selective review of molecules targeting DNA and non-DNA targets. J Nucl Med 46:187S-190S
16. Pauwels B, Korst AEC, Andriessen V, Baay MFD, Pattyn GGO, Lambrechts HAJ, de Pooter CMJ, Lardon F, Vermorken JB (2005) Unraveling the mechanism of radiosensitization by gemcitabine: the role of TP53. Radiat Res 164:642-650

17. Chodoeva A, Bosc JJ, Guillon J, Decendit A, Petraud M, Absalon C, Vitry C, Jarry C, Robert J (2005) 8-O-Azeloyl-14-benzoylaconine: a new alkaloid from the roots of Aconitum karacolicum Rapcs and its antiproliferative activities. Bioorg Med Chem 13:6493-6501

18. de Inés C, Reina M, Gavín JA, González-Coloma A (2006) In vitro cytotoxicity of norditerpenoid alkaloids. Z Naturforsch C 61:11-18

19. Wada K, Hazawa M, Takahashi K, Mori T, Kawahara N, Kashiwakura I (2007) Inhibitory effects of diterpenoid alkaloids on the growth of A172 human malignant cells. J Nat Prod 70:1854-1858

20. Hazawa M, Wada K, Takahashi K, Mori T, Kawahara N, Kashiwakura I (2009) Suppressive effects of novel derivatives prepared from Aconitum alkaloids on tumor growth. Invest New Drugs 27:111-119

21. Hazawa M, Takahashi K, Wada K, Mori T, Kawahara N, Kashiwakura I (2009) Structure-activity relationships between the Aconitum $\mathrm{C}_{20}$-diterpenoid alkaloid derivatives and the growth suppressive activities of non-Hodgkin's lymphoma Raji cells and human hematopoietic stem/progenitor cells. Invest New Drugs (in press). doi:10.1007/s10637-009-9327-4

22. Wada K, Bando H, Amiya $\mathrm{T}$ (1985) Two new $\mathrm{C}_{20}$-diterpenoid alkaloids from Aconitum yesoense var. macroyesoense (Nakai) Tamura. Structures of dehydrolucidusculine and $N$-deethyldehydrolucidusculine. Heterocycles 23:2473-2477

23. Bando H, Wada K, Amiya T, Kobayashi K, Fujimoto Y, Sakurai T (1987) Studies on Aconitum species V. Constituents of Aconitum yesoense var. macroyesoense (Nakai) Tamura. Heterocycles 26:2623-2637

24. Wada K, Bando H, Kawahara N (1990) Studies on Aconitum species XIII. Two new diterpenoid alkaloids from Aconitum yesoense var. macroyesoense (Nakai) Tamura. VI. Heterocycles 31:1081-1088

25. Ogura H, Tsukumo Y, Sugimoto H, Igarashi M, Nagai K, Kataoka T (2008) ERK and p38 MAP kinase are involved in downregulation of cell surface TNF receptor 1 induced by acetoxycycloheximide. Int Immunopharmacol 8:922-926

26. Lee JW, Min HY, Han AR, Chung HJ, Park EJ, Park HJ, Hong JY, Seo EK, Lee SK (2007) Growth inhibition and induction of G1 phase cell cycle arrest in human lung cancer cells by a phenylbutenoid dimer isolated from Zingiber cassumunar. Biol Pharm Bull 30:1561-1564

27. Nguyen TT, Tran E, Ong CK, Lee SK, Do PT, Huynh TT, Nguyen TH, Lee JJ, Tan Y, Ong CS, Huynh H (2003) Kaempferol-induced growth inhibition and apoptosis in A549 lung cancer cells is mediated by activation of MEK-MAPK. J Cell Physiol 197:110-121

28. Nakagawa M, Oliva JL, Kothapalli D, Fournier A, Assoian RK, Kazanietz MG (2005) Phorbol ester-induced $G_{1}$ phase arrest selectively mediated by protein kinase $\mathrm{C} \delta$-dependent induction of p21. J Biol Chem 280:33926-33934

29. Mirzoeva OK, Das D, Heiser LM, Bhattacharya S, Siwak D, Gendelman R, Bayani N, Wang NJ, Neve RM, Guan Y, Hu Z, Knight Z, Feiler HS, Gascard P, Parvin B, Spellman PT, Shokat KM, Wyrobek AJ, Bissell MJ, McCormick F, Kuo W-L, Mills GB, Gray JW, Korn WM (2009) Basal subtype and MAPK/ERK kinase (MEK)-phosphoinositide 3-kinase feedback signaling determine susceptibility of breast cancer cells to MEK inhibition. Cancer Res 69:565-572 